\title{
Identifying hazards in complex ecological systems. Part 3: Hierarchical Holographic Model for herbicide tolerant oilseed rape
}

\author{
Keith R. HAYES ${ }^{1, *}$, Peter C. GREGG ${ }^{2}$, V.V.S.R. GUPTA ${ }^{3}$, R. JESSOP ${ }^{2}$, W.M. LONSDALE ${ }^{4}$, B. SINDEL ${ }^{2}$, \\ J. STANLEY ${ }^{2}$ and C.K. WILLIAMS ${ }^{5}$ \\ ${ }^{1}$ CSIRO Marine Research, GPO Box 1538, Hobart, Tasmania 7001, Australia \\ ${ }^{2}$ School of Rural Science and Agriculture, University of New England, Armidale, NSW 2351, Australia \\ ${ }^{3}$ CSIRO Land and Water, PMB No. 2, Glen Osmond, SA 5064, Australia \\ ${ }^{4}$ CSIRO Entomology, GPO Box 1700, Canberra, ACT 2601, Australia \\ 5 CSIRO Sustainable Ecosystems, GPO Box 284, Canberra, ACT 2601, Australia
}

This paper is the third in a series designed to demonstrate the application of rigorous, systematic hazard identification techniques to ecological systems. Here we use Hierarchical Holographic Modelling to identify the potential ecological hazards associated with the commercial release of herbicide tolerant oilseed rape. Hierarchical Holographic Models decompose complex systems into a series of sub-systems and consider interactions between the components and processes of these sub-systems in order to identify hazards. In this example we considered 1356 potential interactions between the biological, chemical and physical components and processes of the herbicide tolerant oilseed rape environment, and identified 152 potential hazards, grouped into 14 categories. The hazards were subsequently scored for degree of concern and plausibility, and then compared with an equivalent list of hazards generated independently by a checklist approach. The incidence of herbicide tolerant volunteers (and weeds) both on and off the farm had the highest average score of all the ecological hazard categories. The checklist based approach identified or implied $44 \%$ of the hazards identified in the Hierarchical Holographic Model, including nine of the ten hazards ranked most important. The checklist approach focussed almost exclusively on the phenotypic and genotypic hazards associated with herbicide tolerant oilseed rape and largely ignored the hazards associated with the circumstances surrounding its use. As a result the checklist identified only 6 out of the 79 potential hazards associated with changes to farming practice. The commercial release of herbicide tolerant oilseed rape will be associated with changes in tillage and the application of post-emergent herbicides. It may also lead to changes in spray schedules of insecticide and fungicide. Many of the environmental hazards identified with these changes are plausible and may warrant further investigation or targeted monitoring.

Keywords: Herbicide tolerant oilseed rape / hazard analysis / risk assessment

\section{INTRODUCTION}

Hazard identification is arguably the most important component of any risk assessment. Hazards that are not identified in the early stages of a risk assessment may not be carried through the assessment, leading ultimately to underestimates of risk. Hazard identification techniques also play two other important roles within a risk assessment: first they are an effective and appropriate way to involve stakeholders and other interested parties in the risk assessment - indeed the views and opinions of these groups often provide a deeper and richer appreciation of the problem in hand (Stern and Fineberg, 1996). Second, they can help in the design of statistically valid monitoring strategies by highlighting where and when to look for potential adverse events.

\footnotetext{
* Corresponding author: keith.hayes@csiro.au
} 
Hazard identification for all new technologies, including Genetically Modified Organisms (GMOs), initially must be inductive. As operating experience grows, and adverse events are recorded, the analysis can also adopt deductive approaches. The most common (deductive) approaches are unstructured brainstorming and checklists. Checklists may be lengthy and well developed (OGTR, 2001; 2003) or quite cursory (OECD, 1992), and are clearly the "status quo" in the majority of risk assessment frameworks for GMOs (Hayes, 2002a). Checklists do not ask "what can go wrong" with a system, and can lead one to believe that all possibilities have been considered when potentially important interactions or events have been unconsciously ignored.

These concerns are particularly pertinent to ecological systems. Ecological hazards may manifest themselves in natural and agricultural environments, they may move from one to the other, and cut across all levels of biological organisation. Furthermore, ecological hazards can arise through subtle, multi-stage events often involving complex interactions and feedback between physical, biological and chemical components and processes. In these circumstances, systematic inductive hazard identification techniques are more likely to identify potential hazards than deductive techniques that only rely on the operating experience of the analyst and their ability to comprehensively collect their thoughts.

This paper is the third in a series designed to demonstrate the application of inductive hazard identification techniques to ecological systems. The first two papers in this series (Hayes, 2002b; 2002c) focus on fault tree analysis and failure modes and effects analysis. This paper applies a third technique - Hierarchical Holographic Modelling (HHM) - to identify potential ecological hazards associated with the commercial release of Herbicide Tolerant (HT) oilseed rape (OSR), Brassica napus. It does not aim to identify hazards specific to a particular genetic construct. The demonstration does not therefore apply to a particular variety of HT OSR nor identify particular herbicides or release conditions in a particular environment. It does, however, identify the general types of ecological hazards that may be associated with broad acre cropping of HT OSR in Australia. In a real analysis of a GMO intended for release, the identification of hazards would be supported by product-specific and geography-specific information that is not presented here.

This is the first time that inductive hazard identification techniques have been applied in earnest to a GMO. Recently, simple fictitious fault-trees have been mooted (National Research Council, 2002) but the advantages and pitfalls of inductive hazard identification techniques, as applied to complex ecological systems, have yet to be fully explored. The example portrayed here is not polished - it represents the first tentative steps into a demanding but important component of best-practice ecological risk assessment for GMOs.

\section{METHODS}

Large complex systems typically consist of multiple, linked sub-systems, nested within a hierarchy, that interact in a non-linear fashion. One of the basic rules of risk analysis is to understand the relationships among the many components and processes of each sub-system and the way they interact with other sub-systems in the hierarchy. The high dimensionality (large number of variables) and complexity (non-linear interactions) of such large systems present daunting hurdles to the risk analyst (Haimes, 1981; 2001).

HHM captures the complexity of a large system by identifying the biotic and abiotic components and processes of all sub-systems and suggests ways in which they might interact with each other based on established/supportive information. The technique decomposes the system by looking at it from many different perspectives including, for example, the functions, geo-political boundaries or structures of the system. HHM can be used in one of two ways - as a hazard identification tool or as a comprehensive analytical modelling tool. The analyst constructs a HHM by first identifying the most appropriate perspectives for the problem in hand. These are used to define the sub-systems which in turn are further decomposed into components, processes, functions, etc., which may or may not overlap with other sub-systems. The analyst can investigate the quantitative properties of the system if the functions, components or processes of the system can be described by a series of overlapping models, subject to overall system constraints. The analyst(s) can also identify hazards by comparing potential interactions between the sub-systems in a qualitative fashion. This is best achieved by a team of experts familiar with all of the chosen perspectives.

The most difficult part of constructing a HHM is selecting the most appropriate perspectives, system boundaries and level of aggregation or reductionism in the model. Here the focus of study is the analysis of the ecological implications of HT OSR. It deliberately avoids socio-political or economic perspectives, although we did consider how human behavior might generate ecological hazards. We also avoid a specific geographic perspective (such as a particular agricultural region of 
Australia) because this is simply a demonstration of the technique rather than an actual hazard analysis. The perspectives chosen for this analysis therefore focus on the anthropogenic, biological, chemical and physical components and processes of the environment that define the following sub-systems: biological hierarchy; biological components; biological processes; physical components; physical processes; chemical processes and components; anthropogenic components; and, anthropogenic processes. Together, these sub-systems provide a suitable description of the OSR crop environment. Each sub-system is further partitioned into its constituent parts, as deemed most appropriate by the assessment team. For example, the biological component sub-system lists all organisms that might occur in the HT OSR environment by major biological group, for example micro-organisms, plants, insects, other invertebrates, birds, mammals, reptiles/fish/amphibians and humans. Similarly, a list of biological processes can comprehensively include all known processes such as growth, decay, predation, excretion, etc. (Fig. 1).

The hazard identification proceeds by examining a system matrix (Fig. 2). The study team was asked to suggest potential ecological hazards by considering a series of pair-wise interactions between the constituent parts of each sub-system, i.e., within each cell of the matrix. The number of pair-wise interactions $(p w i)$ is given by the number of cells $(C)$ in the matrix and number of interactions $(I)$ within each cell

$$
p w i=C \times I \text {. }
$$

The number of cells in the matrix is determined by the number of sub-systems or perspectives $(p)$ in the HHM, i.e., the number of columns in Figure 1

$$
C=\left[\frac{p(p-1)}{2}\right],
$$

whilst the number of interactions depends on the constituent parts $(s)$ of the two sub-systems $i$ and $j$ compared within each cell of the matrix

$$
I=\sum_{i=1}^{n} \sum_{j=1}^{m}\left(s_{i} \times s_{j}\right) .
$$

In this analysis, the study team was asked to consider 1356 interactions within the HT OSR environment for their potential to cause adverse ecological impacts. The study team comprised an ecologist, soil biologist, agronomist, two entomologists, two weed scientists and a risk analyst. The team met on five occasions (one of which was via video conference), totalling a period of approximately five days, in order to complete the hazard matrix.
Initially, hazards were identified without reference to their likelihood or consequence. Subsequently, each member of the study team was asked to score their degree of concern (high, medium, low) with each hazard and their degree of confidence (from $0.1,0.2, \ldots$ to 1 ) in the plausibility of the hazard. Each team member's score for concern (high $=3$, medium $=2$ and low $=1$ ) was multiplied with their degree of confidence to provide a final hazard score. We report here the mean and variance of the team's hazard scores. The final hazard score does not represent a formal assessment of risk or uncertainty; it is simply a way to prioritise each of the hazards for further analysis. In particular, some hazards which are probably quite unlikely might have received a disproportionately high hazard score because one team member, perhaps unfamiliar with that particular biological process or group of organisms, over-rated the plausibility or the severity of the consequences. This type of uncertainty is reflected in the variance of the hazard score.

During the hazard identification process, some of the pair-wise comparisons did not identify any hazards whilst others elicited several. Furthermore, the same hazard was often identified by more than one pair-wise comparison. Null sets (comparisons that do not identify hazards) are inevitable with such a rigorous and systematic approach - we did not discard any potential interactions prior to the assessment. Duplication (the same hazard identified by more than one comparison) often indicates multiple event chains leading to the same undesired event - in this manner the HHM model adds additional value to the hazard identification process by identifying the different circumstances by which an undesired event might be realized.

\section{RESULTS}

The analysis identified a total of 152 potential hazards, 12 potential benefits and 33 event scenarios that may present a benefit or a hazard depending on the specific environmental and agricultural conditions. These 197 events were grouped into 14 broad hazard categories including three that are not (strictly speaking) ecological: these categories being social, criminal and product segregation. Table 1 lists all the potential events identified in the analysis, ranked by hazard score. Approximately $41 \%$ of events were identified only once. A further $43 \%$ of events were identified between two and four times, whilst two events (1\%) were identified over 15 times.

It is important to note that the analysis did not actively seek to identify potential benefits - the ratio of hazards to 


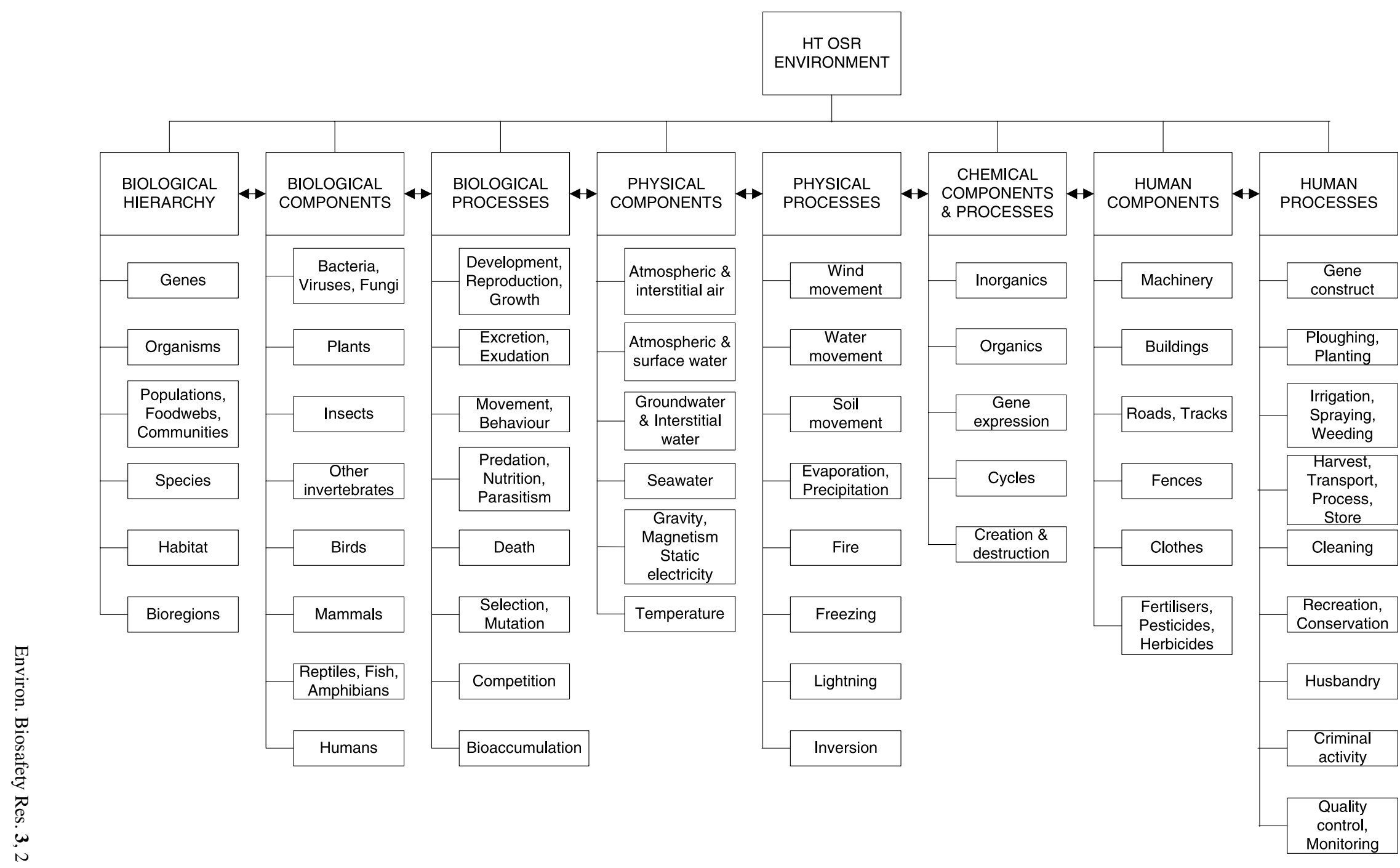


HHM for HT oilseed rape

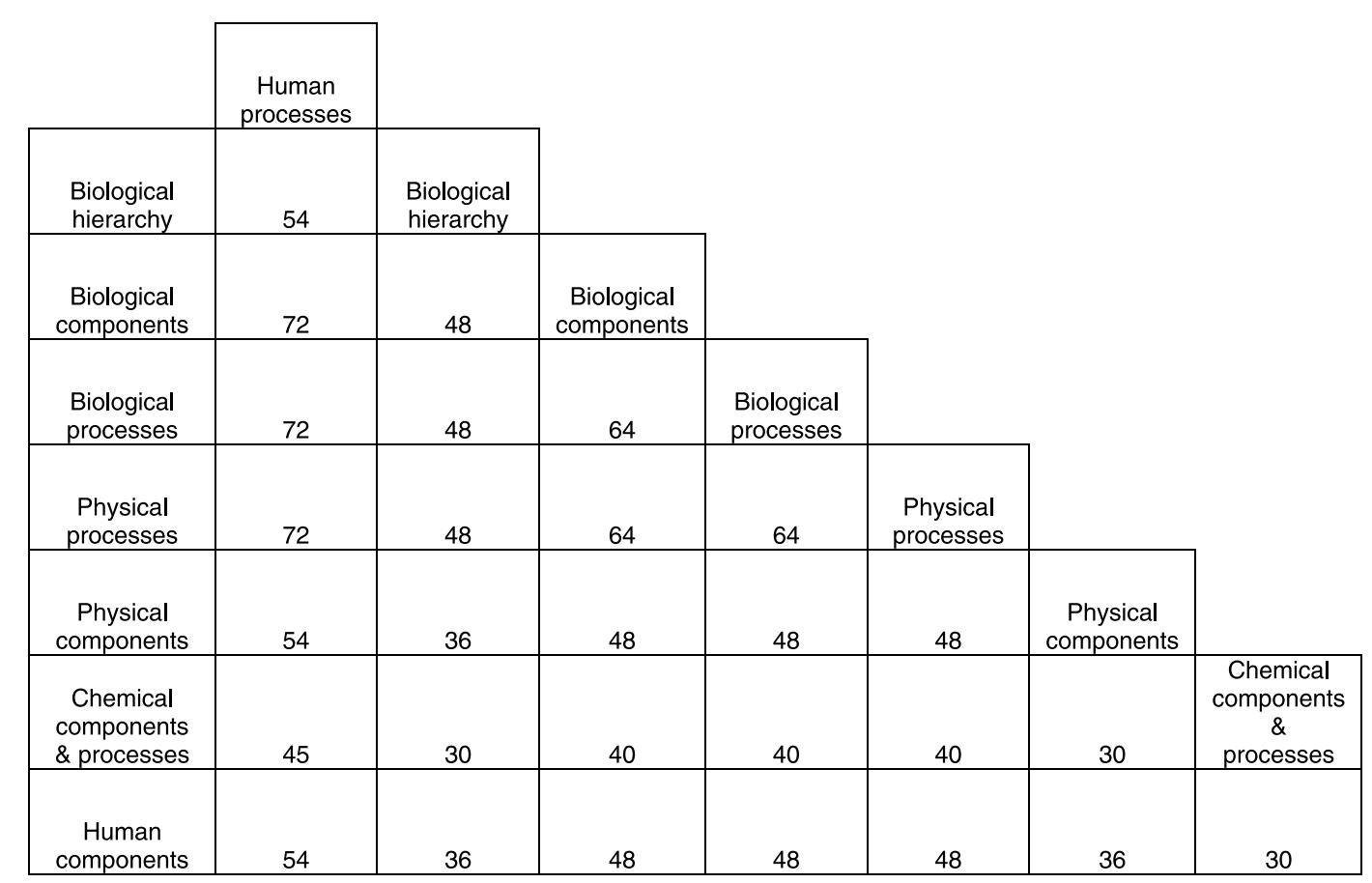

Figure 2. The HT OSR hazard matrix. Numbers within each cell represent the number of pair wise comparisons between the constituent parts of the sub-systems defined by the HHM. The sum of the numbers within the cells is the total number of potential interactions.

benefits in this study is not in any way indicative of the cost-benefit ratio which might result from the introduction of HT OSR to any given area. In many instances the potential events identified in this study are not unique to HT OSR and may occur (or even be more significant) in conventional OSR crops. This possibility is not addressed here. However, it is interesting to note that the potential costs and benefits of biotechnology may only be assessed properly by applying a much greater level of scrutiny to conventional agricultural practice (National Research Council, 2002). The following is a brief account of the 14 broad hazard categories identified in the HHM analysis.

\section{HT volunteers on-farm}

The incidence of HT volunteers (and HT weeds) on the farm has the highest average score of all the ecological hazard categories - i.e., the events in this category were ranked as the most plausible or created the most concern amongst the team. This category, however, also has the highest average variance, of all the ecological categories, indicating that the team's scores were far from unanimous. HT volunteers on farm may occur due to seed loss during harvest and via a variety of natural process (e.g., ants and earthworms) that encourage seed burial and re-emergence. HT volunteers could contaminate subsequent crops and may necessitate their destruction. Here we assume that some form of segregation may be necessary to prevent contamination of certified or non-HT OSR seed. Farmers must also invest time and resources to monitor for volunteers and may use more toxic, destructive or labor-intensive weed control strategies to eliminate HT volunteers on the farm and immediate border areas following HT OSR crops. These are events that, subsequent to the HHM analysis, we observed on many HT trial sites in Tasmania.

\section{HT dispersal off-farm}

Dispersal of the HT gene beyond the farm (off-site) has the second highest average score and variance of the ecological hazard categories identified here, again indicating substantial disagreement over the team's level of concern and/or plausibility. There are many ways in which the HT gene might disperse beyond the farm, either as HT OSR pollen and seed, or as HT pollen and seed of a weedy relative following gene flow, albeit at 
very low frequencies (Rieger et al., 2002). The most significant losses of HT OSR seed will probably occur along seed transport routes (Crawley and Brown, 1995). Significant losses may also occur around OSR meal processing and/or storage plants. Other important anthropogenic vectors of OSR seed and pollen include: contaminated machinery, especially hired or contract machinery; vehicles; soil movements; stock movements; the clothing and activities of farm personnel; whole plant movements (root ball soil); walkers or flower collectors; theft, legal and illegal seed sales; and, waste disposal of spoilt, low quality or excess HT OSR seed, and seedcleaning residues. Contaminated machinery may carry seed, contaminated soil and even pollen, for example in air filters and inaccessible crevices and ledges.

Biological vectors of OSR seed and pollen (in order of likely significance) are insects, birds, mammals, reptiles and amphibians, whilst physical vectors include wind and surface waters. Most pollen is probably dispersed by insects which operate over short ranges $(1 \mathrm{~km}$ or less), such as honey bees (Ramsay et al., 1999). However, some potential insect vectors such as noctuid moths are capable of transporting pollen hundreds of kilometres (Gregg, 1993). Birds and mammals may disperse seed via ingestion/excretion or simply through mud on feet or fouling of plumage and fur, or even twig collections. However, the extent to which OSR seeds remain viable after passing through an animal's gut is largely unknown and undoubtedly differs among taxa. An Australian feeding study recorded small amounts of germinable OSR seed excreted from sheep for up to 5 days after it was last consumed (quoted in OGTR, 2003). Anecdotal evidence from Canada suggests that OSR seed remained viable and subsequently emerged after being fed to chickens and distributed as chicken manure spread on a field 12 months later (quoted in OGTR, 2002). The viability of OSR pollen after extended periods of time on insect vectors (other than honey bees) does not appear to have been investigated. Further dispersal of the HT gene, via the same biological vectors, is also possible if the gene is successfully integrated into the genome of a weedy relative via vertical or horizontal gene flow.

The dispersal of the HT gene beyond the farm has been proposed as a potential negative side effect of the unconfined release of HT OSR. OSR is thought to reduce levels of beneficial soil microbes, such as mycorrhiza (Gavito and Miller, 1998). The extent to which this might impact on off-site plant and soil communities is not known. Conventional OSR, however, is only a significant weed in disturbed habitats, and does not persist in significant numbers in undisturbed natural habitats
(OGTR, 2002), and HT OSR is not thought to differ significantly in this respect (Salisbury, 2000). Attempts to remove HT volunteers in areas outside of the farm, particularly in recreation or conservation areas, may have physical, biological and chemical knock-on effects such as trampling and introduction of weeds and harmful pathogens by personnel and equipment, and non-target impacts of (the potentially more toxic) herbicides required to eliminate HT varieties.

\section{Biodiversity}

Adverse changes to weed spectra were the most frequently identified hazard of HT OSR. The average score and variance were ranked sixth and fifth respectively. Farming practice associated with HT OSR, particularly the expected increase in post-emergent herbicide applications of a chemical with a single mode of action and subsequent selection of herbicide resistant hybrids or volunteers, may increase the resources available to pests of the Brassicaceae whilst at the same time reducing the resources available to beneficial insects and invertebrates. This may cause OSR pest numbers to increase, damaging the crop and/or encouraging farmers to apply higher levels of pesticides and insecticides. Similar effects have recently been claimed for $B t$ cotton in China (Nanjing Institute of Environmental Sciences, 2002), however, there is no evidence for such changes in insect biodiversity with $B t$ cotton in Australia except for declines in the abundance of specific parasites of major cotton pests, an effect probably limited to within the crop (Fitt and Wilson, 2002).

The study team also noted the possibility of a decline in OSR varieties in Australia if a single (or very few) HT OSR variety is widely adopted. This may locally reduce the OSR gene pool and thereby increase susceptibility of the crop as a whole to pathogens such as blackleg (Leptosphaeria maculans). New generations of blackleg resistant HT OSR are being promoted to help avoid this.

\section{Segregation}

As noted above, segregation may be required for reasons of seed purity or may be demanded to maintain organic farming certification and/or consumers choice of GMfree products. Segregation has the fourth highest average score, and the third highest variance. Maintaining separate production, transport and processing streams may lead to minor ecological impacts such as pollution of surface waters with cleaning products and disturbance/habitat loss for non-agricultural purposes (through additional 
building requirements). Segregation may reduce the farmer's ability to move or sell soil or soil related products (e.g., whole plants), transfer machinery between farms or use certain transport routes, and may also require significant quality control resources. Segregation may also necessitate burning of HT OSR stubble. This may reduce soil borne pathogens (a potential benefit) but would modify the composition of soil microbes and fauna, reduce biological functions and may have a minor effect on soil biochemistry. Crop residues, including stubble, are one of the main sources of carbon for soil biota and stubble retention practises increase the populations of soil microflora and fauna, and improve biological functions essential for crop production and soil health (Pankhurst et al., 1997; Roper and Gupta, 1995). Stubble burning has a negative impact on soil structure and increases soil erosion (Beiderbeck et al., 1980; Donaldson and Marston, 1984).

\section{Unexpected expression}

Unexpected expression of the HT gene (i.e., failure to express, excessive expression, or expression in nontarget parts of the plant) may occur if the plant is stressed by water, temperature, nutrients or insects attracted to damaged plants by kairamones, or simply as a result of pleiotropic uncertainty. Water and temperature stress, for example, are thought to reduce Cry1Ac gene expression in Bt cotton (Daly and Fitt, 2000). Farmers may attempt to compensate for failures of expression by additional irrigation, or application of extra fertiliser or preemergent herbicide. These changes in farming practice may have knock-on effects for the environment (see below). Expression of the HT gene in the root and root hairs of OSR may modify root exudates, which may have important implications for soil microfauna, fauna and bio-geochemical cycles. This is known to occur in $B t$ corn (Zea mays) where high concentrations of $B t$ toxin have been recorded in the rhizosphere soil (Saxena et al., 1999) and in Bt cotton where rhizosphere biota populations are different from that of conventional cotton (Gupta et al., 2001). To date, however, only minor changes have been recorded in microbial communities in the rhizosphere of HT OSR plants (Gyamfi et al., 2002). Unexpected expression has a medium average score and average variance (ranked seventh and sixth respectively).

\section{Unexpected selection}

Unexpected selection may occur via a series of physical, chemical or biological events. Pesticide and fertilizer drift and/or run-off may select for certain plants or weeds in environments adjacent to OSR crops, GM or otherwise. This may be more significant for HT OSR, however, if this process selects for weedy relatives capable of hybridizing with the GM plant. Similarly irrigation may select for plants that flower and grow at similar times to OSR and thereby increase the potential for, or rate of, out-crossing. Additional post-emergent herbicide sprays associated with HT OSR crops may also select for plants that have naturally high levels of herbicide tolerance. Again this may or may not increase out-crossing rates. The selection of ecotypes that are naturally tolerant to herbicide may also result in losses to the plant gene pool, both locally and regionally. Herbicide resistance in plants and microbes is also likely to develop in response to additional herbicide application or a reduction in the types of herbicides used (see farming practice below). The significance of these hazards, however, needs to be weighed against the negative impacts of alternative strategies for managing weeds that are implemented for conventional OSR. Furthermore, the magnitude and extent of impact of such hazards, if expressed, would be influenced greatly by the extent of use of HT OSR. OSR is also thought to be slightly tolerant of frost (OGTR, 2002) and salt (Steppuhn et al., 2001), although this is not enhanced in HT varieties (OGTR, 2002; Redmann et al., 1994). Nonetheless OSR volunteers may have a slight competitive advantage in saline soils, areas subject to frost or sea-spray. OSR is also known to tolerate higher levels of boron, an element which is a problem in salt affected soils in southern Australia. Unexpected selection had a relatively high average score (ranked fifth) but a relatively low variance (ranked ninth).

\section{Unexpected invasion}

The overall average score and variance of unexpected invasion is low (ranked eleventh and twelfth respectively). Unexpected invasion is most likely to occur via weedy hybrids or HT volunteers aggregated along fencelines and/or road-sides. These areas are known to harbor weeds and volunteers and are a source of propagules for invasion into fields and adjacent habitats (Pessel et al., 2001). These propagules would have a competitive advantage in the presence of the subject herbicide, applied directly or via drift into these adjacent environments. Competitive advantage (or disadvantage), leading to unexpected invasion dynamics, may occur in a variety of other ways. Less competitive varieties of OSR may be selected in the laboratory - the so-called laboratory 
weakling scenario. This would act to reduce invasiveness and therefore is seen as a potential benefit. Alternatively, the gene product may confer a competitive advantage to the HT OSR seed, although this is considered to be relatively unlikely. Experiments to date suggest that there is no significant difference between transgenic HT OSR plants and non-transgenic plants in survival or the number of seeds per plant (Snow et al., 1999). Other possible, but relatively unlikely scenarios include: HT OSR volunteers exhibiting different flowering patterns in natural areas compared with arable areas, thereby confounding predictions regarding spread or colonisation based on arable characteristics; and, OSR seed or pollen is transported and aggregated beyond the planted field or farm, by hoarding insects or surface water run-off.

\section{Farming practice}

The largest source of ecological hazards (identified in this analysis) is associated with potential changes to farming practice that may follow widespread use of HT OSR. Most of these hazards are associated in one way or another with either the way in which HT OSR is grown such as closer crop rotations, minimum till and postemergent application of herbicides - or with the farmer's potentially more attentive behavior to a high value/high return crop - such as increasing acreage into marginal or remnant land areas and altered spray strategies for a range of insect pests and weeds. Many of the individual hazards within this category feature prominently in the highest scoring hazards, often with low variance (Tab. 1). Overall, however, the average category score and variance rank ninth and seventh.

Some of the hazards identified in the analysis presume that high value OSR will encourage increased HT OSR acreages in existing agricultural land. Without careful management this would increase the rate of outcrossing to weedy relatives, encourage the development of herbicide resistance, and inhibit or impact on organic farming operations. Herbicide resistance may develop in on-site weeds via selection and in off-site weeds through transgene transfer. Increased herbicide resistance in weeds, on and off-site, is the most important hazard identified in this section. Techniques to manage herbicide resistance (such as ploughing) may also degrade soil and encourage soil erosion.

An increase in acreage of HT OSR into non-agricultural areas may be accompanied by a series of ecological impacts similar to those associated with conventional agriculture, as well as a suite of impacts unique to GM crops. Agriculture (conventional or otherwise) often reduces native habitats and remnant vegetation and causes significant changes to soil biogeochemistry. Fields, fences, roads and tracks may present barriers to migration, fragment the natural landscape, facilitate invasion by introducing weeds, pests and pathogens, and disturb natural communities that otherwise provide biotic resistance to the establishment of non-native species and native weeds (Mack, 1996). The extent to which these impacts are associated with HT OSR will be difficult to determine because gene technology is only one of many factors (such as market price and demand for OSR oil) that determine the acreage under OSR.

New agricultural activity may place additional demands on surface and ground water for irrigation purposes or threaten these resources through the run-off of herbicides, pesticides and insecticides. Irrigation may attract fauna to bodies of open water in new agricultural areas and thereby increase their potential exposure to agricultural chemicals. However, HT OSR may encourage precision farming techniques that will help to minimize chemical drift and non-point pollution. Increased acreages of HT OSR into new temperate zones may lead to a number of subtle changes in the plants' physiology. Farmers may attempt to compensate for the influence of temperature stress on gene expression by additional irrigation or application of fertilizer. Additional fertilizer may also be applied because of the greater yield potential of OSR or may be needed in subsequent crops because of the potentially adverse effect of OSR on beneficial soil fungi, e.g., mycorrhizae (Thompson et al., 2001).

The flowering pattern of HT OSR may vary from one temperate zone to another, leading to an increase (or decrease) in out-crossing rate above and beyond that directly attributable to the increased acreage alone. Furthermore, the rate at which farm chemicals degrade and the sensitivity of fauna and flora to these chemicals may vary among temperate zones, either augmenting or reducing their potential impacts above or below that predicted from existing OSR regions. The movement of OSR crops into new regions also may introduce new pests and pathogens into these areas.

An increase in HT OSR acreage might cause a decrease in pasture acreage, in mixed farming regions, and reduce options for crop rotation. Decreased pasture acreages may reduce non-point pollution of surface waters by animal waste (a potential benefit) but encourage more feed lot production and potential point source pollution. Reduced options for rotation of crops may have positive or negative impacts on soil moisture regimes, chemistry and microbial and soil fauna communities. 
Some HT OSR crops may cause an increase in disease severity in following crops by affecting plant nutrition and pathogen-plant interactions. For example, evidence from the mid-western USA suggests that use of glyphosate in glyphosate-tolerant soy beans increased the severity of take-all disease in subsequent winter wheat crops (Hickman et al., 2002).

A variety of ecological effects may occur even if acreages of HT OSR do not increase. Farming practise may change in at least three important ways if HT OSR replaces conventional OSR in existing agricultural regions: increases in minimum tillage and applications of post-emergent herbicide, and changes to spray schedules of insecticide and fungicide.

Minimum tillage tends to favor perennial weeds and may encourage seedling pests such as red legged earth mites and wireworms. Seeds tend to remain on the surface of the soil for longer and may attract birds and rodents (increasing the potential for seed dispersal and exposure to farm chemicals). Minimum tillage in combination with diversification of crops, contributed to a tripling of the frequency of mouse plagues in the graingrowing regions of Victoria and Queensland (Singleton and Brown, 1999). Minimum tillage may also select for seedling vigor and persistence, thereby increasing invasion potential, and prolong the effect of root exudates on soil microbes, increasing the impact of exudates above that of conventional OSR and beyond that potentially associated with the gene construct. Minimum tillage may increase populations of soil biota (a potential benefit) and modify the functional composition of soil microflora and fauna (Roper and Gupta, 1995). Additionally minimum tillage may encourage bioaccumulation of pesticides in soil, reduce levels of soil erosion (a potential benefit), and retain soil moisture, causing cooler soils, increase organic matter and change mineralisation rates (the effects of which differ based on soil type and climate).

Post emergent spraying may make HT OSR less competitive (relative to weedy hybrids), and more susceptible to pests and pathogens, because of the stress it places on the plant. For example, glyphosate is known to inhibit the production of phytoalexins that defend against plant pathogens in a number of crops (Termorshuizen and Lotz, 2002). Post emergent spraying also involves finer sprays and higher spray height than pre-emergent sprays, and may therefore increase levels of herbicide drift although this may be offset by precision farming practises (see above).

Post-emergent application of herbicide and/or increased application of herbicide may lead to a larger biomass of slowly decaying crop residue (root and shoot) material than weed control strategies based on pre-emergent spraying. This may select for certain weeds and fungi, and may also have important implications for microbial diversity and function (such as organic matter turn-over, nutrient mineralisation and disease suppression). For example, a well-known side effect of glyphosate and glufosinate ammonium is the emergence of "herbicide synergists" - opportunistic root pathogens that accelerate the death of herbicide sensitive roots. These synergists may be more aggressive in HT OSR fields because of the increased mass of decaying root material (Termorshuizen and Lotz, 2002). Soil microbial communities, including beneficial microflora, may also be influenced by additional root exudates that may be proportional to the rate at which herbicide is applied to the crop.

The farmer may change schedules of insecticide and fungicide spray because HT OSR has a higher value than conventional OSR. This may lead to more acute and chronic impacts on leaf litter communities, soil microbes, non-target insects, birds, mammals, reptiles, amphibians, etc., and increase levels of surface water pollution. Finally, there is a variety of potential socio-economic impacts associated with the large-scale adoption of HT OSR such as dependence on limited seed suppliers, reliance on a single crop variety, and implications for bee-keepers. These were not explored in detail in this analysis.

\section{Gene flow}

Gene flow is perhaps the most obvious and widely publicized source of hazard associated with HT OSR. This is discussed in detail in numerous other publications (see for example Rieger et al., 1999; 2002; Wilkinson et al., 2000). Here we simply note that gene flow may occur at a very low rate via insects, wind, soil and gut bacteria, viruses or fungi, and by combinations of these vectors (Snyder et al., 1999). Gene flow may be augmented in disturbed areas (e.g., road sides) because of increased numbers of weedy relatives and volunteers, and the increased activity of seed/pollen transport vectors (birds, mice, trucks, etc.). Gene flow to other GM plants may lead to "gene stacking" (Orson, 2002). The assessment team gave a high score to the concern and plausibility of hybridisation via insect pollination, together with a relatively low variance, but the low plausibility and concern of hazards associated with horizontal gene flow (hazards 156,158 and 160) reduce the overall score of this category (ranked eighth). 


\section{Toxicity}

Toxicity hazards have a low average score and low variance (ranked twelfth and tenth respectively) because glyphosate and glufosinate ammonium are known not to bioaccumulate, biomagnify or persist in the soil (Snow et al., 1999; Solomon and Thompson, 2003). Root exudates, biofumigants or the herbicide residues associated with the plant appear to have a minor impact on soil microbe diversity and function (Gyamfi et al., 2002). This may have (minor) implications for decomposition, organic matter turn-over, biogeochemical cycles (nitrogen, phosphorus, sulphur, etc.), disease suppression and soil structure, depending on soil type and conditions. Root exudates, biofumigants and/or the genetic construct may also influence soil insects and other organisms. Other potential hazards identified here are allelopathy, intoxication of birds, reptiles, mammals, etc., and allergenicity in humans. However, there is no evidence of toxic or allergic effects in any of these groups in the HT OSR strains developed to date (OGTR, 2003).

\section{Plant physiology}

The HT construct may have a number of impacts on the plant's physiology including rate and timing of pollen production, rate of pollen decomposition, static and/or allergic properties, seed viability, dormancy, longevity, maturity period (yield lag) and chromosome mutation rate. It may also alter pod shattering characteristics, seed hardness and dispersal characteristics. All of these effects may or may not increase the plant's invasive potential in agricultural and natural environments. Evidence to date, however, suggests that HT OSR is not significantly different from conventional OSR in any of these traits (OGTR, 2003; Salisbury, 2000), and consequently the assessment team were unanimous in allocating low scores to the hazards in this category (the average score and variance of this category ranked lowest). The construct may also alter root phenology and biopore development, frost and salt tolerance, and the plant's water use characteristics (e.g., rate of evapotranspiration). Again, however, these hazards were considered to be relatively implausible.

\section{Plant biochemistry}

The HT construct may lead to a series of subtle, but potentially significant, changes in the plant's biochemistry. These changes may be caused by the HT gene or its associated genes, for example the non-specific phospho- rylation activity of the marker genes (Harding and Harris, 1997). One of the more significant concerns in this context is the possibility that HT OSR diverts metabolic energy into the GM protein and away from other natural pest resistance processes, thereby increasing its susceptibility to pests. Again, however, the agronomic characteristics and pest potential of HT OSR lie within the normal range of values displayed by conventional OSR (OGTR, 2003; Salisbury, 2000).

The HT gene also may cause an increase in nitrogen and other nutrient contents of the leaves. It seems unlikely (but possible) that this could influence the survival of immature insects that have co-evolved with lower levels of nitrogen in conventional OSR or increase the nutritional value of the leaves to adult insects. Similarly, the construct may have a small effect on the nitrogen/carbohydrate ratio in the plant's cells, with positive or negative implications for the food chains of insects that feed on OSR (e.g., aphids and their parasites). Finally, the construct may affect the biofumigant properties of the plant and/or its relationship with beneficial fungi (e.g., vesicular-arbuscular mycorrhizae), parasites or insects, and the chemical composition of the plant residues and stubble inputs into the soil. Again, however, the team were generally in agreement in allocating a low score to these hazards (ranked tenth, variance ranked eleventh).

\section{DISCUSSION}

Table 1 and Figure 3 compare the hazards identified in this document with those identified by an actual risk assessment of HT OSR using a checklist based approach (OGTR, 2003). Table 1 lists the hazards that were identified in the HHM, identified in the HHM and the checklist, and implied but not specifically identified in the checklist. Figure 3(d) plots the average plausibility against the average concern for all of the hazards identified in the HHM analysis. Hazards that were not identified in the checklist, implied by the checklist and identified in the checklist are distinguished in Figures 3(a), 3(b) and 3(c) respectively. The size of the symbols in each case is proportional to the variance of the hazard score.

A reasonable correlation between plausibility and concern is evident for those hazards implied by and identified by the checklist (Fig. 3b - Spearman's rho statistic $=0.65$; and Fig. $3 \mathrm{c}-$ Spearman's rho statistic $=$ 0.76). The hazards identified by the checklist reflect "established knowledge" that the assessment team were well appraised of. In these circumstances it is (perhaps) 

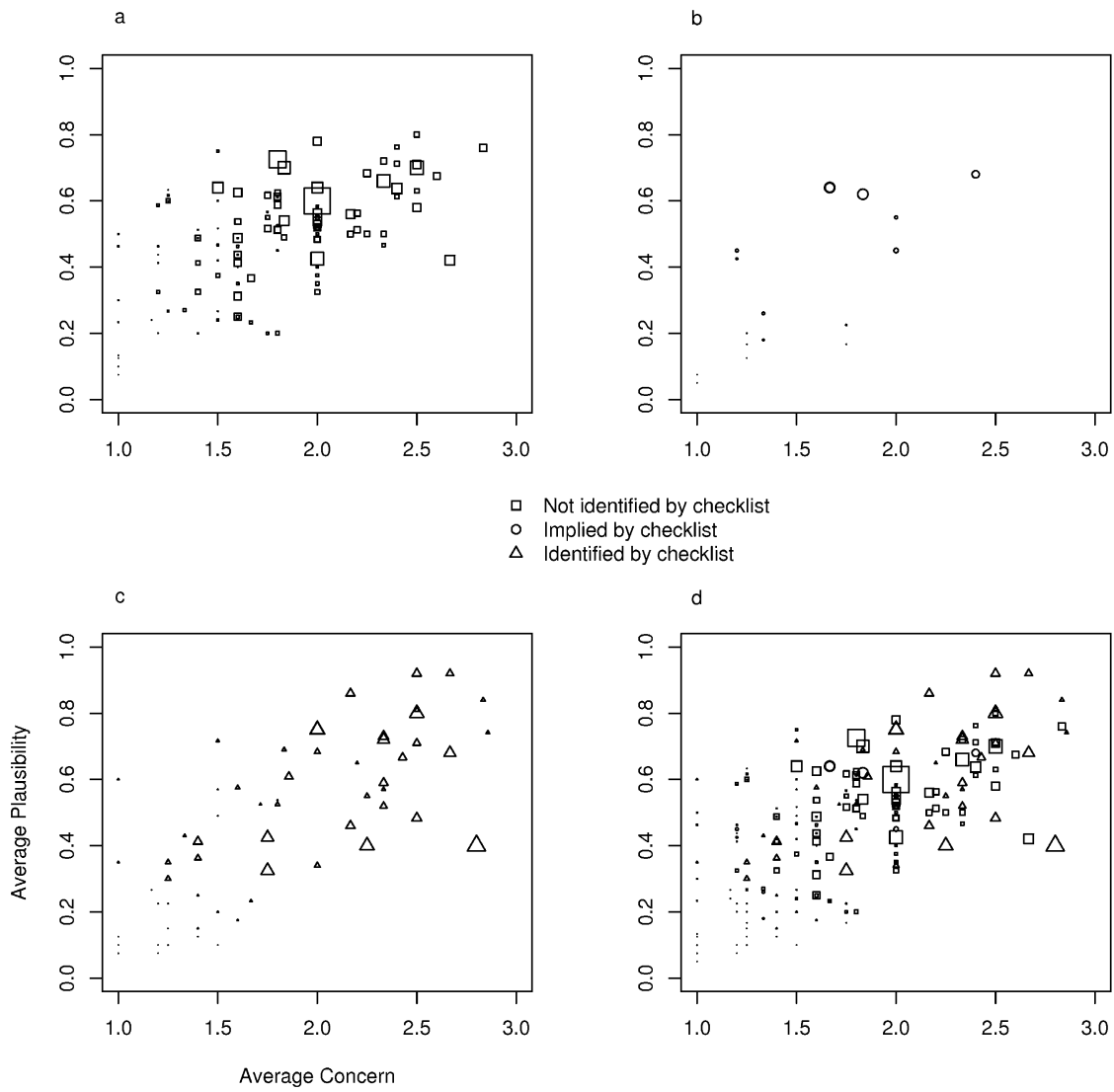

Not identified by checklist

- Implied by checklist

$\triangle$ Identified by checklist

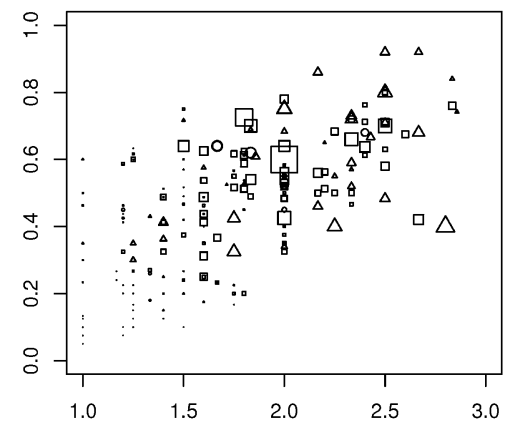

Figure 3. The average concern and average plausibility of the hazards identified in the HHM analysis (d) that were: (a) not identified in an equivalent checklist; (b) implied in the checklist; and, (c) identified in the checklist. The size of the symbols is proportional to the variance of the hazard score.

unsurprising that the assessment team were unable to separate, and independently score, concern and plausibility - concern is bound up with prior knowledge of plausibility gained from the existing literature, giving rise to correlated scores. The same effect, however, is less evident in the hazards that were not identified in the checklist (Fig. 3a - Spearman's rho statistic $=0.57$ ). These hazards reflect new or "speculative knowledge" about which there is much less existing evidence of plausibility, and hence plausibility is less likely to form part of the assessor's concern. Clearly the HHM analysis, like all forms of hazard analysis and risk assessment, is sensitive to the body of existing knowledge, and by logical corollary, would vary as new knowledge emerged. The utility of the HHM analysis lies in identifying which new hazards may warrant further investigation and thereby help generate new information in an efficient manner.

It is also clear from the size of the symbols in the bottom left quadrant of Figure 3(d) that the HHM analysis identified a large number of hazards that the assessors unanimously scored with low plausibility and low concern. This suggests there is some scope for pruning subsequent (more specific) assessments by focussing on the interactions in the HMM matrix that gave rise to higher scored hazards with greater variance.

The variance of the hazard score, and indeed the actual hazards, reflects the make-up of the assessment team. Subsequent assessments may be able to reduce variance and identify other hazards by tailoring the expertise of the assessment team to the interactions (or groups of interactions) assessed in the HHM matrix. For example it is possible that the variances associated with farming practice interactions may have been lower if conventional and/or HT OSR farmers had contributed to the hazard analysis process. It is important to recognize, however, the assessment team used here were expert in the biological, ecological and agronomic characteristics of the OSR environment, and subsequent assessments should, in the first instance, focus on the hazards plotted in the top right quadrant of Figure 3(a).

\section{CONCLUSION}

This paper demonstrates the application of a rigorous hazard identification technique to the potential hazards 
associated with HT OSR. The importance of this demonstration lies in both the hazards that have been identified and the event chains that may or may not lead to these hazards. This approach emphasises that a hazard is a function of the intrinsic properties of a substance or activity (e.g., the phenotype of GM plants) and the circumstances surrounding this activity. Risk assessment of GM plants must therefore address their transgenic phenotypes and the circumstances surrounding their release.

The HHM analysis helps identify potentially important circumstances by exposing the diversity of mechanism (e.g., different dispersal vectors) and means (e.g., standard farming practice, ecological response and farmer response) by which hazardous events may occur. The HHM analysis identifies a broad suite of ecological hazards. Many of these hazards are relatively obvious and would have been (and indeed were) identified with a checklist or via unstructured brainstorming. Some of the hazards, however, are more subtle and involve quite complex event chains, and for these reasons may not have been suggested without a structured, rigorous hazard identification procedure. In this comparison the checklist identifies or implies $44 \%$ of the hazards identified by the HHM analysis (excluding hazards associated with segregation, social and criminal activity because these were not included within the risk assessment), including nine of the hazards ranked as the ten most important by our team (excluding segregation hazards).

The checklist, however, failed to identify a number of quite plausible hazards such as dispersal via disposal of spoilt or low quality seed; the effects of herbicide drift; and the effect of temperature, moisture or insect-induced stress on gene expression. Perhaps more importantly the checklist based approach focussed almost exclusively on the phenotypic and genotypic hazards associated with HT OSR (i.e., the substance) and not the circumstances surrounding its use (i.e., farming practice). As a result the checklist identified only 6 out of the 79 potential hazards associated with changes to farming practice. The environmental hazards associated with increases in minimum till and post-emergent herbicide application, and changes to spray schedules of insecticide and fungicide may warrant further investigation or targeted monitoring, especially in situations where HT OSR is grown more frequently in the same field. Farming practice may be the most important factor controlling the environmental impacts of conventional (Gaugitsch, 2002) and GM agriculture.

The HHM analysis did not distinguish between hazards that are specific to the GM technology and those associated with agriculture more generally. As a result some of the hazards noted here might be more important in conventional systems. In these circumstances, GM technology may offer substantial benefits over current practise. As noted above, however, conventional agricultural practice has not, to date, been subject to the same level of "before the event" scrutiny as biotechnology. Without this information it is difficult to accurately gauge the potential costs or benefits of the new technology.

The main drawback with the HHM analysis is the time required to complete it, and the need to co-ordinate experts that, as in this case, might be drawn from several different institutions. It is often difficult to maintain continuity and consistency in these groups. Redundancy and duplication within the analysis also tends to reduce its efficiency. This analysis can be used to identify possibly redundant (low score, low variance) interactions in any subsequent assessment of HT OSR, but for new assessments it would be difficult to determine a priori where redundancy is likely to occur. The first assessments of a complex new technology must try to explore all possibilities; thereafter more streamlined approaches to hazard analysis, which require less time, can be developed. HHM analysis is a "bottom up" approach that helps to identify new hazards. Thereafter it can be complemented, or even replaced, by "top down" techniques, such as fault tree analysis, that focus on particular endpoints (Hayes, 2002b).

HHM analysis is not an "objective" process - its heuristic potential and usefulness depends on the expertise of the analyst(s), and in this sense it is no less sensitive to the expertise of the analysts involved than any other hazard analysis or risk assessment technique. HHM analysis helps analyst(s) deconstruct complex systems into their contributing parts, so long as they are sufficiently familiar with the system in question. It requires substantial expert knowledge, and is ultimately limited by knowledge of the people involved in the analysis. It is therefore most useful when conducted by a team of experts who are able to pool their collective expertise. Checklists may be quicker and easier than HHM but otherwise suffer from the same types of problems discussed here and, importantly, provide even less confidence that all possible hazards have been addressed for new technologies. Demonstrably thorough hazard identification is an important pre-cursor to risk assessment and public confidence in risk based environmental management of novel technologies such as GMOs. Extra investment in the early stages of an ecological risk assessment will therefore provide substantial benefits throughout the remainder of the process and help harness the maximum potential benefits from novel technologies such as GMOs. 


\section{HHM for HT oilseed rape}

Table 1. Ranked potential hazards (and benefits) associated with HT OSR: hazards identified by the HHM and those identified $(\checkmark)$, implied (-) or not identified (x) in an equivalent checklist approach.

\begin{tabular}{|c|c|c|c|c|c|c|}
\hline HazCat $^{\mathrm{a}}$ & HazID & Potential hazard & $+/-$ & Checklist & $\mathrm{AS}^{\mathrm{b}}$ & $\mathrm{VS}^{\mathrm{c}}$ \\
\hline 4 & 28 & Off-site transport of HT OSR seed via farm machinery (impossible to clean completely) & - & $\checkmark$ & 2.56 & 0.75 \\
\hline 5 & 49 & Subsequent crop seed contaminated by HT OSR seed & - & $\checkmark$ & 2.51 & 0.36 \\
\hline 4 & 33 & Off-site transport of HT OSR pollen by pollinating insects (incl. long distance noctuids) & - & $\checkmark^{\mathrm{d}}$ & 2.27 & 0.63 \\
\hline 5 & 53 & Additional monitoring needed for volunteers \& other HR weeds & - & $\checkmark$ & 2.26 & 0.73 \\
\hline 7 & 57 & HT OSR requires segregation from harvest to process to consumer & - & $\mathrm{x}$ & 2.20 & 0.80 \\
\hline 10 & 157 & Gene stacking possibility following hybridisation with another GM plant & - & $\checkmark$ & 2.08 & 0.64 \\
\hline 9 & 99 & $>$ acreage of HT OSR $>$ weed tolerance development ${ }^{\mathrm{e}}$ & - & $\checkmark$ & 2.03 & 0.29 \\
\hline 9 & 125 & $\begin{array}{l}\text { Altered spray schedules, insecticides \& fungicides (because of }>\text { valued crop) has acute } \\
\& \text { chronic impacts on non-target insects }\end{array}$ & - & $\mathrm{x}$ & 2.01 & 0.71 \\
\hline 4 & 22 & Seed dispersal ( $\&$ accumulation) along transport routes & - & $\checkmark$ & 2.00 & 0.44 \\
\hline 5 & 48 & Significant seed loss during harvest & - & $\checkmark$ & 2.00 & 1.16 \\
\hline 7 & 62 & $\begin{array}{l}\text { Different building (process, storage, drum master, waste disposal) required if segregation } \\
\text { required }\end{array}$ & - & $\mathrm{x}$ & 1.98 & 0.56 \\
\hline 9 & 151 & Bee-keeper avoidance of HT OSR regions & $+/-$ & $\checkmark$ & 1.97 & 0.84 \\
\hline 9 & 150 & Organic farming operations inhibited in HT OSR regions & - & $\mathrm{x}$ & 1.93 & 0.89 \\
\hline 4 & 29 & $\begin{array}{l}\text { Off-site transport of HT OSR seed via soil (e.g. equipment, tools, erosion, subsequent } \\
\text { crops, soil samples, boots) }\end{array}$ & - & - & 1.85 & 0.80 \\
\hline 6 & 56 & Erosion of clean, green, organic image in areas where HT OSR is grown & na & $\mathrm{x}$ & 1.85 & 1.45 \\
\hline 12 & 175 & $\begin{array}{l}\text { Accumulation of pesticides in localised areas via predominant wind, water or soil } \\
\text { movement }\end{array}$ & - & $\mathrm{x}$ & 1.80 & 0.58 \\
\hline 2 & 9 & $\begin{array}{l}\text { Plants have chemical defences \& various levels of HT that will be selected } \\
\text { by }>\text { herbicide application }\end{array}$ & - & $\mathrm{x}$ & 1.75 & 0.44 \\
\hline 4 & 23 & $\begin{array}{l}\text { Waste disposal of cleaning waste, spoilt, low quality or excess HT seed may lead } \\
\text { to dispersal }\end{array}$ & - & $\mathrm{x}$ & 1.74 & 0.49 \\
\hline 4 & 43 & GM pollen spreads into conservation areas & - & $\checkmark$ & 1.67 & 1.00 \\
\hline 4 & 32 & Off-site transport of HT OSR pollen by wind (incl. fire generated thermals, inversions) & - & $\checkmark$ & 1.66 & 1.18 \\
\hline 9 & 124 & $\begin{array}{l}\text { Altered spray schedules of insecticides \& fungicides (because of }>\text { valued crop) } \\
\text { has acute \& chronic impacts on microbes }\end{array}$ & - & $\mathrm{x}$ & 1.66 & 0.87 \\
\hline 9 & 153 & Construct or associated farming practise facilitates herbicide resistance in weeds & - & $\checkmark$ & 1.66 & 0.99 \\
\hline 9 & 76 & $>$ acreage of HT OSR cultivation > impact on soil biological functions & - & $\mathrm{x}$ & 1.64 & 0.55 \\
\hline 9 & 73 & HT OSR $<$ crop rotation options ${ }^{\mathrm{f}}$ & - & $\mathrm{x}$ & 1.61 & 0.65 \\
\hline 9 & 109 & $>$ fertilizer if $>$ yield potential $>$ non-point pollution & - & $\mathrm{x}$ & 1.54 & 0.75 \\
\hline 9 & 143 & $>$ volume of herbicide $>$ root exudation & - & $\mathrm{x}$ & 1.52 & 0.37 \\
\hline 6 & 54 & Public do not accept GM technology & na & $\mathrm{x}$ & 1.50 & 2.88 \\
\hline 1 & 3 & Eco-physiological stress $<$ expression $>$ conventional herbicide application & - & $\mathrm{x}$ & 1.48 & 0.23 \\
\hline 7 & 58 & HT OSR requires segregation if unsuitable for pet bird seed & - & $\mathrm{x}$ & 1.47 & 1.38 \\
\hline 4 & 39 & $\begin{array}{l}\text { Additional cultivation to remove HT OSR from unwanted areas (e.g. buffer zone) } \\
\text { degrades soil structure }\end{array}$ & - & $\checkmark$ & 1.45 & 0.35 \\
\hline 5 & 50 & Farmer needs alternative ( $>$ toxic) weed management strategy to eliminate HT volunteers & - & $\checkmark$ & 1.43 & 0.67 \\
\hline 4 & 30 & $\begin{array}{l}\text { Off-site transport of HT OSR seed via sale or movement (legal or illegal) } \\
\text { of contaminated stock (e.g. mud on hooves) }\end{array}$ & - & $\mathrm{x}$ & 1.42 & 0.86 \\
\hline 9 & 120 & Minimum till associated with HT OSR alters surface run-off \& drainage & - & $\mathrm{x}$ & 1.42 & 0.59 \\
\hline 4 & 24 & Off-site transport of HT OSR seed via birds (plumage, gut, etc.) & - & $\checkmark$ & 1.32 & 0.73 \\
\hline 2 & 11 & Weed eco-type strains selected along with herbicide tolerance - loss of plant gene pool & - & $\mathrm{x}$ & 1.31 & 0.14 \\
\hline
\end{tabular}


Table 1. Continued.

\begin{tabular}{|c|c|c|c|c|c|c|}
\hline HazCat $^{\mathrm{a}}$ & "HazID & Potential hazard & +/- & Checklist & $\mathrm{AS}^{\mathrm{b}}$ & $\mathrm{VS}^{\mathrm{c}}$ \\
\hline 5 & 47 & Bioturbation (earthworms, ants, etc.) $>$ seed burial depth & $+/-$ & $\mathrm{x}$ & 1.31 & 0.92 \\
\hline 7 & 65 & Cannot sell soil used to grow HT OSR if segregation required & - & $\mathrm{x}$ & 1.31 & 1.86 \\
\hline 9 & 84 & $\begin{array}{l}\text { > acreage of HT OSR > herbicide \& insecticide application in new areas - effects on insect/ } \\
\text { invertebrate fauna }\end{array}$ & - & $\mathrm{x}$ & 1.31 & 0.45 \\
\hline 9 & 127 & Altered spray schedules - insecticides $\&$ herbicides $\&$ fungicides $>$ surface water pollution & - & $\mathrm{x}$ & 1.30 & 0.56 \\
\hline 1 & 4 & Temperature stress affects gene expression (e.g. failure to express)? & - & $\mathrm{x}$ & 1.29 & 0.92 \\
\hline 11 & 162 & $\begin{array}{l}\text { Decreasing OSR variety diversity in Australian acreage }<\text { the gene pool }>\text { susceptibility } \\
\text { to pathogens (e.g. black leg) }\end{array}$ & - & $\checkmark$ & 1.29 & 0.58 \\
\hline 9 & 118 & $\begin{array}{l}\text { Minimum till associated with HT OSR encourages bioaccumulation of pesticides } \\
\text { (if they reach soil) }\end{array}$ & - & $\mathrm{x}$ & 1.28 & 0.93 \\
\hline 4 & 37 & HT OSR in roadsides can only be removed with more toxic herbicides & - & $\checkmark$ & 1.27 & 0.50 \\
\hline 10 & 155 & HT gene flow to weedy relatives (via insect pollinators) & - & $\checkmark$ & 1.27 & 0.81 \\
\hline 9 & 77 & $>$ acreage of HT OSR cultivation $>$ pressure on remnant vegetation \& native plants & - & $\mathrm{x}$ & 1.26 & 1.13 \\
\hline 9 & 154 & $\begin{array}{l}\text { Resistance management may require re-introduction of ploughing which has implications } \\
\text { for soil degradation \& soil erosion. }\end{array}$ & - & $\mathrm{x}$ & 1.25 & 1.33 \\
\hline 9 & 95 & $>$ acreage of HT OSR into non-agricultural areas \&/or $>$ herbicide \& pesticides $<$ air quality & - & $\mathrm{x}$ & 1.24 & 0.75 \\
\hline 9 & 91 & $>$ acreage of HT OSR into non-agricultural areas $<$ air quality (pollen, dust) & - & $\mathrm{x}$ & 1.23 & 0.72 \\
\hline 9 & 149 & Reliance on one crop $>$ susceptibility to pests \& pathogens & - & $\mathrm{x}$ & 1.22 & 0.40 \\
\hline 5 & 51 & Destruction of subsequent crop & - & $\checkmark$ & 1.20 & 0.24 \\
\hline 4 & 31 & Off-site transport of HT OSR seed via losses from seed meal processing plants & - & - & 1.18 & 0.33 \\
\hline 9 & 88 & $>$ acreage of OSR directly $>$ out crossing rate & - & $\mathrm{x}$ & 1.17 & 1.07 \\
\hline 10 & 159 & $\begin{array}{l}\text { Gene flow augmented in disturbed areas due to }>\text { weeds, volunteers, unusual wind } \\
\text { conditions, birds, mice movement }\end{array}$ & - & $\mathrm{x}$ & 1.16 & 0.96 \\
\hline 9 & 100 & $>$ acreage of HT OSR alters carbon turn-over $\&$ affects soil creation & - & $\mathrm{x}$ & 1.12 & 1.41 \\
\hline 9 & 132 & $\begin{array}{l}>\text { post emergent spraying }>\text { monitoring for (pesticide/herbicide) residues }>\text { exposure } \\
\text { of personnel }\end{array}$ & - & $\mathrm{x}$ & 1.11 & 0.77 \\
\hline 1 & 7 & Gene expression in the roots modifies exudation & - & $\checkmark$ & 1.10 & 1.49 \\
\hline 9 & 96 & $\begin{array}{l}>\text { acreage of HT OSR into non-agricultural areas } \& / \text { or }>\text { herbicide } \& \text { pesticides }<\text { surface } \\
\text { water quality issues }\end{array}$ & - & $\mathrm{x}$ & 1.10 & 0.23 \\
\hline 9 & 128 & $\begin{array}{l}>\text { post emergent spraying makes HT OSR }<\text { competitive because of stress placed on the plant } \\
\text { by the herbicide. }\end{array}$ & + & $\checkmark$ & 1.09 & 0.08 \\
\hline 7 & 61 & Different machinery required if segregation required & - & $\mathrm{x}$ & 1.09 & 1.17 \\
\hline 1 & 1 & Water stress affects gene expression (may > root exudation) & - & $\mathrm{x}$ & 1.08 & 0.21 \\
\hline 14 & 199 & $\begin{array}{l}\text { HT OSR diverts metabolic energy into GM protein, away from other insect/invertebrate pest } \\
\text { resistance processes > susceptibility }\end{array}$ & - & $\checkmark$ & 1.07 & 0.77 \\
\hline 3 & 19 & $\begin{array}{l}\text { Aggregation of weedy hybrids or volunteers along fence lines = haven for HT OSR \& OSR } \\
\text { pathogens }\end{array}$ & - & $\checkmark$ & 1.06 & 0.32 \\
\hline 9 & 106 & Different irrigation regime influences soil temperature & $+/-$ & $\mathrm{x}$ & 1.06 & 0.80 \\
\hline 9 & 121 & Minimum till associated with HT OSR $<$ soil loss & + & $\checkmark$ & 1.05 & 0.36 \\
\hline 9 & 130 & $\begin{array}{l}>\text { post emergent spraying (finer droplets) }>\text { herbicide drift (under temperature inversion } \\
\text { conditions) }>\text { impact on beneficials }\end{array}$ & - & $\mathrm{x}$ & 1.03 & 0.63 \\
\hline 9 & 114 & Minimum till associated with HT OSR - effect on dormancy \& persistence of volunteer seed & $+/-$ & $\checkmark$ & 1.02 & 0.24 \\
\hline 12 & 171 & $\begin{array}{l}\text { HT OSR root exudates or biofumigants have lethal or sub-lethal effects on soil microbes, } \\
\text { insects or invertebrates }\end{array}$ & - & $\checkmark$ & 1.01 & 1.02 \\
\hline 9 & 83 & $\begin{array}{l}>\text { acreage of HT OSR }>\text { herbicide } \& \text { insecticide application in new areas - effects on flora } \\
\text { (e.g. nectar availability) }\end{array}$ & - & $\mathrm{x}$ & 1.01 & 0.67 \\
\hline 4 & 38 & HT OSR in national parks can only be removed with more toxic herbicides & - & $\checkmark$ & 1.01 & 0.70 \\
\hline 12 & 163 & $\begin{array}{l}\text { HT OSR (+ residues), lethal or sub-lethal effects on soil microbe diversity \& function } \\
\text { (decomposition, OM turn-over, } N \& \text { S levels) }\end{array}$ & - & $\checkmark$ & 1.00 & 1.18 \\
\hline 14 & 194 & $\begin{array}{l}\text { Construct affects N levels in HT OSR leaves }>\text { nutritional value }>\text { insects on HT OSR > } \\
\text { insecticide or < yield }\end{array}$ & - & $\checkmark$ & 0.98 & 0.37 \\
\hline
\end{tabular}




\section{HHM for HT oilseed rape}

Table 1. Continued.

\begin{tabular}{|c|c|c|c|c|c|}
\hline$\overline{\text { HazCat }}{ }^{\mathrm{a}}$ & HazID & Potential hazard & & lecklist & $\mathrm{AS}^{\mathrm{b}} \mathrm{VS}^{\mathrm{c}}$ \\
\hline 9 & 85 & $\begin{array}{l}>\text { acreage of HT OSR }>\text { herbicide } \& \text { insecticide application in new areas - effects on birds, } \\
\text { mammals, reptiles, amphibians, fish }\end{array}$ & - & $\mathrm{x}$ & 0.980 .67 \\
\hline 2 & 10 & $\begin{array}{l}\text { Selection of herbicide-tolerant microbes (because of additional application) reduces efficacy } \\
\text { of herbicide? }\end{array}$ & - & $\checkmark$ & 0.950 .43 \\
\hline 4 & 27 & Off-site transport of HT OSR seed via clothing & - & - & 0.931 .14 \\
\hline 9 & 97 & $\begin{array}{l}>\text { acreage of HT OSR into non-agricultural areas } \& / \text { or }>\text { herbicide } \& \text { pesticides }<\text { ground water } \\
\text { quality }\end{array}$ & - & $\mathrm{x}$ & 0.930 .43 \\
\hline 4 & 35 & Off-site transport of HT OSR pollen via clothing & - & - & 0.911 .14 \\
\hline 9 & 144 & $\begin{array}{l}\text { Tram line effects associated with spray intensive HT OSR changes surface water run-off }>\text { soil } \\
\text { erosion }\end{array}$ & - & $\mathrm{x}$ & 0.900 .61 \\
\hline 4 & 40 & Additional cultivation to remove HT OSR from unwanted areas $>$ seed burial & $+/-$ & $\checkmark$ & 0.890 .06 \\
\hline 4 & 36 & $\begin{array}{l}\text { Off-site transport of HT OSR pollen and plant residues via contaminated machinery \& air filters } \\
\text { (incl. emergency/utility vehicles) }\end{array}$ & - & - & 0.891 .03 \\
\hline 9 & 131 & > post emergent spraying makes HT OSR less desirable as feed due to herbicide residues & - & $\mathrm{x}$ & 0.850 .08 \\
\hline 4 & 44 & $\begin{array}{l}\text { GM volunteers in recreation/conservation areas < beneficial (e.g. mycorrhiza) \& introduce } \\
\text { pathogenic soil microbes. }\end{array}$ & - & $\mathrm{x}$ & 0.830 .24 \\
\hline 5 & 52 & Seed accumulation at equipment cleaning or storage sites & - & $\checkmark$ & 0.831 .24 \\
\hline 7 & 59 & $>$ cleaning if segregation required $>$ run-off \& non-point pollution (surface, ground, coastal) & - & $\mathrm{x}$ & 0.830 .30 \\
\hline 8 & 69 & Black market in HT OSR seed & - & $\mathrm{x}$ & 0.820 .76 \\
\hline 1 & 2 & Irrigation reduces water stress causing $>$ gene expression & + & $\mathrm{x}$ & 0.800 .27 \\
\hline 4 & 41 & $\begin{array}{l}\text { Additional cultivation/spraying to remove HT OSR from unwanted areas (e.g. fence lines) } \\
\text { damages native plants \& animals }\end{array}$ & - & $\checkmark$ & 0.790 .17 \\
\hline 4 & 34 & Off-site transport of HT OSR pollen \& seed by surface water run-off (incl. irrigation) + aggregation & - & $\mathrm{x}$ & 0.791 .07 \\
\hline 9 & 116 & $\begin{array}{l}\text { Minimum till associated with HT OSR selects for persistence \& thereby }>\text { invasion potential } \\
\text { of HT OSR seed }\end{array}$ & - & $\mathrm{x}$ & 0.780 .57 \\
\hline 9 & 123 & $\begin{array}{l}\text { Minimum till associated with HT OSR leads to increased organic matter, changes timing } \\
\text { of mineralisation rates }\end{array}$ & $+/-$ & $\mathrm{x}$ & 0.770 .13 \\
\hline 9 & 129 & > post emergent spraying damages HT OSR > susceptibility to pests \& pathogens & $+/-$ & $\mathrm{x}$ & 0.770 .15 \\
\hline 7 & 64 & $>$ QC \& monitoring required for inorganic/organic residues if segregation required & + & $\mathrm{x}$ & 0.761 .17 \\
\hline 3 & 20 & Aggregation of HT OSR seed by hoarding insects & - & $\mathrm{x}$ & 0.730 .03 \\
\hline 9 & 138 & $\begin{array}{l}>\text { volumes of herbicide } \& \text { different types of herbicide - effects on microbial diversity \& function } \\
\text { (exudation } \propto \text { to volume) }\end{array}$ & - & $\mathrm{x}$ & 0.730 .20 \\
\hline 1 & 5 & Nutrient stress affects gene expression & - & $\mathrm{x}$ & 0.730 .12 \\
\hline 3 & 16 & HT OSR is selected towards less competitive varieties in the laboratory & + & $\checkmark$ & 0.720 .04 \\
\hline 13 & 189 & Construct $>$ pollen allergenicity & - & $\checkmark$ & 0.720 .53 \\
\hline 9 & 115 & $\begin{array}{l}\text { Minimum till associated with HT OSR selects for seedling vigour } \& \text { thereby }>\text { invasive potential } \\
\text { of HT OSR }\end{array}$ & - & $\mathrm{x}$ & 0.720 .35 \\
\hline 14 & 195 & $\begin{array}{l}\text { Construct affects } \mathrm{N} / \text { carbohydrate ratio - food chain effects for insects that feed on plant } \\
\text { (e.g. aphids \& their parasites) }\end{array}$ & $+/-$ & - & 0.720 .33 \\
\hline 2 & 14 & Brassica growth favored in high salt environments (sea spray, saline soils) & - & $\mathrm{x}$ & 0.720 .34 \\
\hline 9 & 133 & $<$ pasture associated with HT OSR $<$ fire hazard & + & $\mathrm{x}$ & 0.720 .02 \\
\hline 9 & 113 & $\begin{array}{l}\text { Minimum till associated with HT OSR leaves seed on the ground for longer }- \text { attracts }>\text { insects \& } \\
\text { birds including nuisance birds }\end{array}$ & - & $\mathrm{x}$ & 0.680 .09 \\
\hline 14 & 196 & $\begin{array}{l}\text { Construct affects inorganic/organic chemical composition of the plant, stubble inputs into the soil } \\
\& \text { soil bio-geochemical cycles }\end{array}$ & $+/-$ & $\checkmark$ & 0.660 .48 \\
\hline 12 & 173 & HT OSR has allelopathic effects on other plants & - & $\mathrm{x}$ & 0.630 .38 \\
\hline 11 & 161 & $\begin{array}{l}\text { Altered weed spectrum alters hosts for insects }>\text { brassicaceous weeds }>\text { resources to brassica pests } \\
<\text { resources to beneficials }\end{array}$ & - & - & 0.620 .49 \\
\hline 9 & 137 & $>$ volumes of herbicide \& different types of herbicide - effects on soil bio-geochemical cycles? & $+/-$ & $\mathrm{x}$ & 0.620 .36 \\
\hline 9 & 86 & $\begin{array}{l}\text { > acreage of HT OSR leads to insufficient time to clean insect pests from silos \& harvesting } \\
\text { equipment }\end{array}$ & - & $\mathrm{x}$ & $\begin{array}{lll}0.61 & 0.31\end{array}$ \\
\hline 9 & 90 & $\begin{array}{l}>\text { acreage of HT OSR \&/or HT > spectrum (susceptibility) }>\text { international/state transport of pests } \\
\text { (weevils, moths) \& pathogens }\end{array}$ & - & $\mathrm{x}$ & 0.600 .67 \\
\hline
\end{tabular}


Table 1. Continued.

\begin{tabular}{|c|c|c|c|c|c|}
\hline HazCat $^{\mathrm{a}}$ & HazID & Potential hazard & $+/-$ & "ecklist & $A S^{b} V^{c}$ \\
\hline 9 & 134 & $<$ pasture associated with HT OSR $<$ methane & + & $\mathrm{x}$ & 0.600 .02 \\
\hline 9 & 112 & $\begin{array}{l}\text { Minimum till associated with HT OSR leads to > problems with seedling pests (Red Legged Earth } \\
\text { mite, Wire worms) }\end{array}$ & - & $\mathrm{x}$ & 0.600 .57 \\
\hline 9 & 82 & $\begin{array}{l}>\text { acreage of HT OSR ( } \& \text { irrigation) will change insect fauna leading to possible adverse impacts } \\
\text { (e.g. less ants, more pests) }\end{array}$ & - & $\mathrm{x}$ & 0.580 .62 \\
\hline 1 & 6 & Insect pest density affects gene expression (insects attracted by kairomones to damaged plants) & - & $\mathrm{x}$ & 0.560 .04 \\
\hline 9 & 89 & $\begin{array}{l}>\text { acreage of HT OSR \&/or irrigation indirectly }>\text { out crossing rate (may change the flowering } \\
\text { pattern of OSR) }\end{array}$ & - & $\mathrm{x}$ & 0.560 .64 \\
\hline 9 & 98 & $\begin{array}{l}>\text { acreage of HT OSR into non-agricultural areas \&/or }>\text { herbicide \& irrigation (attracts fauna) } \\
>\text { exposure of fauna to chemicals }\end{array}$ & - & $\mathrm{x}$ & 0.560 .11 \\
\hline 9 & 119 & Minimum till associated with HT OSR $<$ levels of soil-borne pathogens & + & $\mathrm{x}$ & 0.560 .10 \\
\hline 4 & 46 & Monitoring for emergence along transport routes $>$ exposure of personnel to traffic accidents & - & $\mathrm{x}$ & 0.560 .09 \\
\hline 9 & 104 & $>$ irrigation to avoid stress induced failure to express & - & $\mathrm{x}$ & 0.540 .68 \\
\hline 14 & 200 & Bioaccumulation of HT OSR metabolites following $>$ herbicide resistance & - & $\mathrm{x}$ & 0.530 .25 \\
\hline 14 & 198 & Construct affects symbiotic relationships with fungi, parasitic plants & $+/-$ & $\mathrm{x}$ & 0.520 .17 \\
\hline 4 & 26 & Off-site transport of HT OSR seed via reptiles, fish or amphibians & - & - & 0.520 .29 \\
\hline 9 & 110 & Minimum till associated with HT OSR favors perennial weeds & - & $\mathrm{x}$ & 0.510 .73 \\
\hline 2 & 15 & $\begin{array}{l}\text { Irrigation selects for weeds that flower or grow in appropriate period }>\text { potential for out crossing } \\
\text { with these species \& HT OSR }\end{array}$ & - & $\mathrm{x}$ & 0.510 .76 \\
\hline 9 & 117 & $\begin{array}{l}\text { Minimum till associated with HT OSR prolongs root exudates } \& \text { therefore }>\text { their affect above } \\
\& \text { beyond conventional OSR }\end{array}$ & - & $\mathrm{x}$ & 0.510 .19 \\
\hline 7 & 60 & Different cleaning compounds if segregation required (effects of this?) & $+/-$ & $\mathrm{x}$ & 0.500 .25 \\
\hline 13 & 185 & Construct affects root phenology \& biopore development & $+/-$ & $\mathrm{x}$ & 0.500 .25 \\
\hline 2 & 12 & Pesticide \& fertiliser drift \& run-off causes selection in adjacent environments & - & $\mathrm{x}$ & 0.480 .24 \\
\hline 3 & 18 & Gene product confers competitive advantage to seed & - & $\checkmark$ & 0.450 .12 \\
\hline 9 & 135 & $<$ pasture associated with HT OSR $<$ surface water pollution by animal waste & + & $\mathrm{x}$ & 0.450 .44 \\
\hline 9 & 140 & $>$ volumes of herbicide $\&$ different types of herbicide - non-target impacts on fauna & $+/-$ & $\mathrm{x}$ & 0.450 .40 \\
\hline 9 & 139 & $\begin{array}{l}>\text { volumes of herbicide \& different types of herbicide - selection for certain fungi }>\text { spore dispersal } \\
\text { of certain spp }\end{array}$ & - & $\mathrm{x}$ & 0.420 .74 \\
\hline 12 & 176 & Toxicity of secondary products following GM protein breakdown? & - & $\checkmark$ & 0.420 .12 \\
\hline 12 & 164 & HT OSR (+ residues) has lethal or sub-lethal effects on soil microbe diversity \& hence soil structure & - & $\checkmark$ & 0.411 .08 \\
\hline 4 & 25 & Off-site transport of HT OSR seed via mammals (fur, gut, etc.) & - & $\checkmark$ & 0.410 .24 \\
\hline 9 & 107 & $>$ fertiliser application to avoid stress induced failure to express \&/or extend OSR & - & $\mathrm{x}$ & 0.400 .75 \\
\hline 4 & 42 & Walkers \& flower collectors inadvertently spread seed, plants or pollen & - & - & 0.400 .19 \\
\hline 9 & 126 & $\begin{array}{l}\text { Altered spray schedules, insecticides \& fungicides (because }>\text { valued crop) }>\text { toxic to non-target } \\
\text { vertebrates }\end{array}$ & - & $\mathrm{x}$ & 0.390 .51 \\
\hline 12 & 169 & HT OSR (+ residues) affects parasitoid micro-environment & - & - & 0.380 .14 \\
\hline 9 & 108 & $>$ fertiliser application needed following HT OSR because of adverse affects on VAM fungi & - & $\mathrm{x}$ & 0.380 .03 \\
\hline 7 & 67 & Burning of stubble if segregation required - reduces soil pathogens & + & $\mathrm{x}$ & 0.370 .06 \\
\hline 9 & 93 & $\begin{array}{l}>\text { acreage of HT OSR into non-agricultural areas }>\text { water demand }>\text { evaporation, surface water } \\
\text { run-off \& non-point pollution }\end{array}$ & - & $\mathrm{x}$ & 0.360 .70 \\
\hline 4 & 45 & Attempts to control HT volunteers leads to $>$ traffic $\&>$ exposure to other harmful microbes & - & $\checkmark$ & 0.350 .14 \\
\hline 10 & 160 & Surface \& ground-water transport of bacteria & $+/-$ & - & 0.350 .03 \\
\hline 9 & 102 & $\begin{array}{l}>\text { irrigation }>\text { water movement }- \text { recharge, drainage }- \text { non-point pollution hazards \& rising water } \\
\text { tables (salinity issue) }\end{array}$ & - & $\mathrm{x}$ & 0.350 .20 \\
\hline 9 & 78 & $\begin{array}{l}>\text { acreage of HT OSR > migration barriers and habitat fragmentation associated with new roads } \\
\text { or tracks }\end{array}$ & - & $\mathrm{x}$ & 0.340 .53 \\
\hline
\end{tabular}




\section{HHM for HT oilseed rape}

Table 1. Continued.

\begin{tabular}{|c|c|c|c|c|c|c|}
\hline HazCat $^{\mathrm{a}}$ & HazID & Potential hazard & $+1-($ & Checklist & $\mathrm{AS}^{\mathrm{b}}$ & 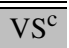 \\
\hline 9 & 103 & $>$ irrigation $>$ evaporative loss (contingent on increased take up over conventional strains). & - & $\mathrm{x}$ & 0.34 & $\overline{0.04}$ \\
\hline 7 & 66 & Burning of stubble if segregation required - soil biogeochemical \& fauna/flora impacts & - & $\mathrm{x}$ & 0.32 & 0.07 \\
\hline 8 & 70 & Vandalism (machinery, buildings, crop) at GM crop sites & - & $\mathrm{x}$ & 0.31 & 0.03 \\
\hline 9 & 92 & $>$ acreage of HT OSR into non-agricultural areas $<$ surface water quality (dust) & - & $\mathrm{x}$ & 0.30 & 0.06 \\
\hline 1 & 8 & Pleiotropic uncertainty & + & $\checkmark$ & 0.30 & 0.75 \\
\hline 9 & 87 & $>$ acreage of HT OSR $>$ precision farming techniques $(<$ pollution and drift) & + & $\mathrm{x}$ & 0.30 & 0.12 \\
\hline 9 & 122 & $\begin{array}{l}\text { Minimum till associated with HT OSR }<\text { evaporation }=\text { cooler soils with implications } \\
\text { for microbes \& chemical reaction rates }\end{array}$ & $+/-$ & $\mathrm{x}$ & 0.30 & 0.11 \\
\hline 10 & 156 & Horizontal gene flow of HT gene to weedy relatives (via bacteria, viruses or fungi) & - & $\checkmark$ & 0.29 & 0.02 \\
\hline 9 & 146 & $\begin{array}{l}\text { Effects of }>\text { traffic volumes (e.g. herbicide tankers) in agricultural areas (accidents, road-kill, } \\
\text { nuisance) }\end{array}$ & - & $\mathrm{x}$ & 0.29 & 0.07 \\
\hline 9 & 74 & $\begin{array}{l}\text { HT OSR }=\text { closer crop rotations }<\text { pasture }- \text { soil chemistry (wet/dry cycles) } \& \text { microbial } \\
\text { implications }\end{array}$ & - & $\mathrm{x}$ & 0.28 & 0.31 \\
\hline 9 & 142 & $\begin{array}{l}>\text { volumes of herbicide \& different types of herbicide }>\text { bioaccumulation in food chain } \\
\text { of herbivores \& predators }\end{array}$ & - & $\checkmark$ & 0.28 & 0.20 \\
\hline 9 & 147 & Corporation farming dependant on limited seed source & - & $\mathrm{x}$ & 0.28 & 0.31 \\
\hline 9 & 111 & Minimum till associated with HT OSR leads to $>$ harvesting ants & - & $\mathrm{x}$ & 0.28 & 0.04 \\
\hline 9 & 101 & $\begin{array}{l}>\text { acreage of HT OSR into new temperature zones changes expected pesticide degradation rates } \\
\text { and species sensitivity }\end{array}$ & - & $\mathrm{x}$ & 0.27 & 0.10 \\
\hline 9 & 79 & $>$ acreage of HT OSR > invasion along "road margins" associated with new roads or tracks & - & $\mathrm{x}$ & 0.26 & 0.98 \\
\hline 9 & 81 & $>$ acreage of HT OSR cultivation $>$ attraction of vertebrate pests to storage areas & - & $\mathrm{x}$ & 0.25 & 0.12 \\
\hline 13 & 177 & $\begin{array}{l}\text { Construct affects pollen production rate } \& \text { timing }>\text { synchronicity of pollination with weedy } \\
\text { relatives? }\end{array}$ & - & $\checkmark$ & 0.25 & 0.02 \\
\hline 12 & 166 & HT OSR (+ residues) has lethal or sub-lethal effects on birds feeding on seed or plant & - & $\checkmark$ & 0.24 & 0.05 \\
\hline 9 & 94 & $\begin{array}{l}>\text { acreage of HT OSR into non-agricultural areas }>\text { water demand }<\text { groundwater infiltration } \\
\& \text { recharge }\end{array}$ & - & $\mathrm{x}$ & 0.24 & 0.47 \\
\hline 9 & 105 & $>$ irrigation $>$ direct impact (pump damage) on fish & - & $\mathrm{x}$ & 0.24 & 0.82 \\
\hline 9 & 136 & $<$ pasture associated with HT OSR $>$ feed lot production $>$ localised concentration of animal waste & - & $\mathrm{x}$ & 0.23 & 0.17 \\
\hline 7 & 63 & Dedicated GM transport routes (e.g. avoid national parks) $\&>$ traffic volumes & - & $\mathrm{x}$ & 0.23 & 0.02 \\
\hline 12 & 165 & $\begin{array}{l}\text { HT OSR (+ residues) has lethal or sub-lethal effects on insects \& other invertebrates } \\
\text { (incl. predatory soil fauna) }\end{array}$ & - & $\checkmark$ & 0.23 & 0.48 \\
\hline 3 & 17 & $\begin{array}{l}\text { Different flowering patterns of HT OSR in recreation/conservation areas changes seed } \\
\text { production, out crossing \& spread. }\end{array}$ & - & $\checkmark$ & 0.23 & 0.42 \\
\hline 9 & 80 & $\begin{array}{l}\text { > acreage of HT OSR cultivation > exposure of new areas to plant pathogens \& weeds via soil } \\
\text { contaminated machinery }\end{array}$ & - & $\mathrm{x}$ & 0.22 & 0.13 \\
\hline 9 & 145 & Non-point pollution on coastal resources (e.g. coral) & - & $\mathrm{x}$ & 0.22 & 0.29 \\
\hline 14 & 193 & $\begin{array}{l}\text { Construct affects N levels in HT OSR leaves - effects survival of immature insects that have } \\
\text { co-evolved with low N }\end{array}$ & $+/-$ & - & 0.21 & 0.21 \\
\hline 9 & 141 & $>$ volumes of herbicide $\&$ different types of herbicide $>$ leaf litter $\&$ changes composition & $+/-$ & $\mathrm{x}$ & 0.20 & 0.09 \\
\hline 12 & 167 & $\begin{array}{l}\text { HT OSR (+ residues) has lethal or sub-lethal effects on reptiles/amphibians feeding on seed } \\
\text { or plant }\end{array}$ & - & - & 0.20 & 0.06 \\
\hline 3 & 21 & $\begin{array}{l}\text { OSR transported by water competes with natives and other desirable pasture plants in riparian } \\
\text { areas }\end{array}$ & - & $\checkmark$ & 0.18 & 0.13 \\
\hline 12 & 170 & HT OSR residues influence soil temperature via different decomposition rate of crop residues & $+/-$ & - & 0.18 & 0.03 \\
\hline 12 & 174 & $\begin{array}{l}\text { HT OSR (+ residues) less palatable or acceptable to insects \& other invertebrates - behavioral } \\
\text { changes? }\end{array}$ & $+/-$ & $\checkmark$ & 0.18 & 0.14 \\
\hline 13 & 186 & $\begin{array}{l}\text { Metabolic cost of protein production < competitive behavior in presence of tolerant weeds/pests } \\
>\text { insecticide use }\end{array}$ & - & $\checkmark$ & 0.17 & 0.10 \\
\hline 9 & 75 & HT OSR $=$ closer crop rotations $=$ changes to soil moisture regime & $+/-$ & $\mathrm{x}$ & 0.17 & 0.07 \\
\hline 12 & 168 & HT OSR (+ residues) has lethal or sub-lethal effects on mammals feeding on seed or plant & - & $\checkmark$ & 0.15 & 0.02 \\
\hline 14 & 197 & Construct affects biofumigant properties of OSR & $+/-$ & - & 0.15 & 0.01 \\
\hline
\end{tabular}


Table 1. Continued.

\begin{tabular}{|c|c|c|c|c|c|c|}
\hline HazCat $^{\mathrm{a}}$ & "HazID & Potential hazard & 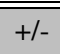 & Checklist & $\mathrm{AS}^{\mathrm{b}}$ & $\mathrm{VS}^{\mathrm{c}}$ \\
\hline 13 & 179 & Construct affects seed viability, dormancy or longevity? & - & $\checkmark$ & 0.14 & 0.03 \\
\hline 13 & 178 & Construct affects pollen production - wind \& water dispersal implications & - & $\checkmark$ & 0.13 & 0.01 \\
\hline 13 & 181 & Construct affects seed shatter characteristics & $+/-$ & $\checkmark$ & 0.13 & 0.00 \\
\hline 13 & 182 & Construct affects seed hardness & $+/-$ & $\checkmark$ & 0.13 & 0.00 \\
\hline 12 & 172 & Gene product causes allergic reaction in man & - & $\checkmark$ & 0.13 & 0.01 \\
\hline 13 & 187 & Construct affects frost tolerance of plant & $+/-$ & $\checkmark$ & 0.12 & 0.00 \\
\hline 8 & 71 & Criminal spread of HT seed & - & $\mathrm{x}$ & 0.12 & 0.00 \\
\hline 8 & 68 & Theft of germplasm & - & $\mathrm{x}$ & 0.11 & 0.00 \\
\hline 8 & 72 & Manufacturer sued for failed gene expression? & - & $\mathrm{x}$ & 0.11 & 0.00 \\
\hline 10 & 158 & Horizontal gene transfer to gut bacteria via insect predation, HT feed & - & $\checkmark$ & 0.11 & 0.00 \\
\hline 13 & 190 & Construct alters pollen decomposition rate (transport \& surface water quality issues) & $+/-$ & $\checkmark$ & 0.10 & 0.01 \\
\hline 13 & 180 & Construct extends seed maturity period (yield lag) & $+/-$ & $\checkmark$ & 0.10 & 0.02 \\
\hline 13 & 188 & Construct alters evapo-transpiration rate of plant & $+/-$ & - & 0.09 & 0.00 \\
\hline 13 & 192 & Construct alters salt tolerance & - & $\checkmark$ & 0.09 & 0.00 \\
\hline 13 & 183 & $\begin{array}{l}\text { Construct affects seed dispersal directly (physiological - lodgment) or indirectly (changes } \\
\text { insect movement patterns) }\end{array}$ & $+/-$ & $\checkmark$ & 0.09 & 0.00 \\
\hline 13 & 184 & Construct affects rate of chromosome mutation & $+/-$ & $\mathrm{x}$ & 0.09 & 0.00 \\
\hline 9 & 152 & Bee-keeper aggregation in HT OSR region $>$ nuisance & - & $\mathrm{x}$ & 0.07 & 0.02 \\
\hline 13 & 191 & Construct alters pollen static properties & $+/-$ & - & 0.05 & 0.00 \\
\hline
\end{tabular}

\section{ACKNOWLEDGEMENTS}

This study was partly funded by Environment Australia under the Commonwealth's National Biotechnology Strategy. We would like to thank Nic Bax, Tony Smith, Mark Tepfer and an anonymous reviewer for their comments, all of which helped improve the manuscript.

Received October 14, 2003; accepted July 19, 2004.

\section{REFERENCES}

Biederbeck VO, Campbell CA, Bowren KE, Schnitzer M, McIver RN (1980) Effect of burning cereal straw on soil properties and grain yields in Saskatchewan. Soil Sci. Soc. Am. 44: 103-111

Crawley MJ, Brown SL (1995) Seed limitation and the dynamics of feral oilseed rape on the M25 motorway. Proc. Roy. Soc. Lond. B 259: 49-54
Daly JC, Fitt GP (2000) Efficacy of Bt cotton plants in Australia: what is going on? In Gillham F, ed, New Frontiers in Cotton Research - Proceedings World Cotton Research Conference - 2, Athens, Sept. 6-12 1998, P. Petridis, Thessaloniki, pp 675-678

Donaldson SG, Marston D (1984) Structural stability of black cracking clays under different tillage systems. Reviews in Rural Science 5: 335-338

Fitt GP, Wilson LJ (2002) Non-target effects of Bt cotton: a case study from Australia. In Akhurst RJ, Beard CE, Hughes $\mathrm{P}$, eds, Proceedings of the 4th Pacific Rim Conference on the Biotechnology of Bt-Environmental Impacts, CSIRO Publishing, Canberra, Australia, pp 175-182

Gaugitsch H (2002) Experience with environmental issues in GM crop production and the likely future scenarios. Toxicol. Lett. 127: 351-357

Gavito ME, Miller MH (1998) Changes in mycorrhiza development in maize induced by crop management practises. Plant Soil 198: 185-192

Gregg PC (1993) Pollen as a marker for Helicoverpa armigera (Hubner) and $H$. punctigera Wallengren (Lepidoptera: 
Noctuidae) emigrating from western Queensland. Aust. J. Ecol. 18: 209-219

Gupta VVSR, Roberts GN, Neate SM, Crisp P, McClure S, Watson SK (2001) Impact of Bt-cotton on biological processes in Australian soils. In Akhurst RJ, Beard CE, Hughes P, eds, Proceedings of the 4th Pacific Rim Conference on the Biotechnology of Bt-Environmental Impacts, CSIRO Publishing, Canberra, Australia, pp 191-194

Gyamfi S, Pfeifer U, Stierschneider M, Sessitsch A (2002) Effects of transgenic glufosinate-tolerant oilseed rape (Brassica napus) and the associated herbicide application on eubacterial and Pseudomonas communities in the rhizosphere. FEMS Microbiol. Ecol. 41: 181-190

Haimes YY (1981) Hierarchical Holographic Modelling. IEEE Transactions on Systems, Man and Cybernetics, 11: 606-617

Haimes YY (2001) Protection of Critical Complex Transportation Infrastructure. http://san-antonio.tamu.edu/ trba5021/Documents/documents.htm

Harding K, Harris PS (1997) Risk assessment of the release of genetically modified plants: A review. Agro-Food Industry Hi-Tech, 8: 8-13

Hayes KR (2002a) Best Practice and Current Practice in Ecological Risk Assessment for Genetically Modified Organisms. Centre for Research on Introduced Marine Pests, CSIRO Marine Research, Hobart, Australia, 78 p

Hayes KR (2002b) Identifying hazards in complex ecological systems. Part 1: Fault tree analysis for biological invasions. Biological Invasions 4: 235-249

Hayes KR (2002c) Identifying hazards in complex ecological systems. Part 2: Infections modes and effects analysis for biological invasions. Biological Invasions 4: 251-261

Hickman MV, Huber DM, Dodds DM (2002) Residual effects of glyphosate on yield and take-all of wheat. WSSA abstracts 2002, Weed Science Society of America 42: 6

Mack NR (1996) Biotic barriers to plant naturalization. In Moran VC, Hoffmann JHG, eds, Proceedings of the IX International Symposium on Biological Control of Weeds, 19-26 January 1996. University of Cape Town, Stellenbosch, South Africa, pp 39-46

Nanjing Institute of Environmental Sciences (2002) Bt Cotton in China. http://www.greenpeace.org/ geneng/ reports/env_impact_eng.pdf

National Research Council (2002) Environmental Effects of Transgenic Plants: The Scope and Adequacy of Regulation. National Academy Press, Washington, USA, $320 \mathrm{p}$

Office of the Gene Technology Regulator (OGTR) (2001) Risk Assessment Framework for License Applications to the Office of the Gene Technology Regulator, November 2001. Office of the Gene Technology Regulator, Canberra, Australia, $80 \mathrm{p}$

Office of the Gene Technology Regulator (OGTR) (2002) The Biology and Ecology of Canola Brassica napus, Office of the Gene Technology Regulator, Canberra, Australia, $33 \mathrm{p}$

Office of the Gene Technology Regulator (OGTR) (2003) Risk Assessment and Risk Management Plan, Application for
Licence for Dealings Involving an Intentional Release into the environment, DIR 021/2002, 22 April 2003. Office of the Gene Technology Regulator, Canberra, Australia, $156 \mathrm{p}$

Organisation for Economic Cooperation and Development (OECD) (1992) Safety considerations for biotechnology. Organisation for Economic Cooperation and Development, Paris, France, $45 \mathrm{p}$

Orson J (2002) Gene Stacking in Herbicide Tolerant Oilseed Rape: Lessons for the North American Experience. English Nature Research Report No. 443, English Nature, Peterborough, England, $17 \mathrm{p}$

Pankhurst CE, Doube B, Gupta VVSR (1997) Biological Indicators of Soil Health. CAB International, Oxford, England

Pessel FD, Lecomte J, Emeriau V, Krouti M, Messean A, Gouyon PH (2001) Persistence of oilseed rape (Brassica napus L.) outside of cultivated fields. Theor. Appl. Genet. 102: $841-846$

Ramsay G, Thompson CE, Mackay GR (1999) Honeybees as vectors of GM oilseed rape pollen. In Gene flow and Agriculture: Relevance for Transgenic Crops. British Crop Protection Council Symposium Proceedings No. 72, April 1999, Keele, Staffordshire, UK, pp 209-216

Redmann RE, Qi MQ, Belyk M (1994) Growth of transgenic and standard canola (Brassica napus $\mathrm{L}$ ) varieties in response to soil-salinity. Can. J. Plant Sci. 74: 797-799

Rieger MA, Preston C, Powles SB (1999) Risks of gene flow from transgenic herbicide-resistant canola (Brassica napus) to weedy relatives in southern Australian cropping systems. Aust. J. Agric. Res. 50: 115-128

Rieger MA, Lamond M, Preston C, Powles SB, Roush RT (2002) Pollen mediated movement of herbicide resistance between commercial canola fields. Science 296: 2386-2388

Roper MM, Gupta VVSR (1995) Management practices and soil biota. Aust. J. Soil Res. 33: 321-339

Salisbury PA (2000) The myths of gene transfer - a canola case study. Plant Protection Quarterly 15: 71-76

Saxena D, Flores S, Stotzky G (1999) Insecticidal toxin in root exudates from Bt corn. Nature 402: 480

Singleton GR, Brown PR (1999) Management of mouse plagues in Australia: Integration of population ecology, biocontrol and best farm practise. In Cowan DP, Feare CJ, eds, Advances in Vertebrate Pest Management, Furth, Filander Verlag, pp 189-203

Snow AA, Andersen B, Jorgensen RB (1999) Costs of transgenic herbicide resistance introgressed from Brassica napus into weedy B. rapa. Mol. Ecol. 8: 605-615

Solomon KR, Thompson DG (2003) Ecological risk assessment for aquatic organisms from over water uses of Glyphosate. J. Toxicol. Environ. Health 6: 289-324

Steppuhn H, Volkmar KM, Miller PR (2001) Comparing canola, field pea, dry bean and durum wheat crops grown in saline media. Crop Sci. 41: 1827-1833

Stern PC, Fineberg HV (1996) Understanding risk: informing decisions in a democratic society. Committee on Risk 
Characterisation. Commission on Behavioural and Social Sciences and Education. National Research Council. National Academy Press, Washington, USA

Snyder WE, Tonkyn DW, Kluepfel DA (1999) Transmission of a genetically engineered rhizobacterium by grasshoppers in the laboratory and the field. Ecol. Appl. 9: 245-253

Termorshuizen AJ, Lotz LAP (2002) Does large-scale cropping of herbicide resistant cultivars increase the incidence of polyphagous soil-borne pathogens? Outlook Agric. 31: $51-54$
Thompson JP, Owen KJ, Clewett TG (2001) Pre-cropping with canola decreases vesicular arbuscular mycorrhizas and growth of wheat in a low phosphorus soil. In Proceedings of the 2nd Australasian Soil Borne Disease Symposium, Lorne, Australia, pp 150-151

Wilkinson MJ, Davenport IJ, Charters YM, Jones AE, Allainguillaume J, Butler HT, Mason DC, Raybould AF (2000) A direct regional scale estimate of transgene movement from genetically modified oilseed rape to its wild progenitors. Mol. Ecol. 9: 983-991

To access this journal online: www.edpsciences.org 